\title{
Performance of mustard (Brassica juncea L.) varieties under Azadirachta indica L. shade and open condition in hot-arid region of Rajasthan
}

\author{
MANOHAR LAL ${ }^{1 *}$, SHEILENDRA KUMAR ${ }^{1}$, S.M. KUMAWAT ${ }^{1}$, R.S. YADAV ${ }^{1}$ and S.K.KHARIA ${ }^{2}$ \\ ${ }^{1}$ Department of Agronomy, ${ }^{2}$ Department of Soil Science, College of Agriculture, \\ S.K. Rajasthan Agricultural University, Bikaner-334 006, Rajasthan \\ *Corresponding Author: manoharla100291@gmail.com
}

\begin{abstract}
The mustard production and productivity of the hot arid region of Rajasthan is dominated by both genetic makeup and environmental conditions. An experiment was conducted with four mustard varieties (RGN-73, RGN-229, RH-30 and Pusa bold) in two growing environments (open environment and neem shade). Pusa bold gave significantly higher plant height than other varieties. Among varieties, RGN-73 had significantly higher number of branches per plant, dry matter accumulation per plant, siliquae per plant, seed yield, stover yield, biological yield, harvest index and heat use efficiency than other varieties. However, significantly higher test weight was in Pusa bold variety. Under open environment condition, significantly higher growth, yield attributes, yield, harvest index and heat use efficiency were found as compared to neem shade environment. The results revealed that variety RGN-229 took more days for completion of life cycle as compared to other varieties, hence RGN-229 variety required significantly more degree days than other varieties. The pheno-thermal index was significantly higher in open condition.
\end{abstract}

Key Words: Phenological stages, growth, yield, growing degree days, heat use efficiency, pheno-thermal index

Mustard (Brassicajuncea L.) is one of the important oilseed crops of the world. Plant origin oil constitute important component of human diet, ranking third after cereals and animal products and are nutritionally superior to animal oil (Alam et al., 2015; Buttar and Aulakh, 1999, FAO, 2007). Rajasthan ranks first both in area and production of mustard in the country. The productivity is quite lower than developed countries mainly due to sub-optimal application of fertilizers and cultivation on marginal lands in rainfed conditions (Kumawat et al., 2014). Varietyselection is the most important decision to achieve higher crop yield by improving the fertilizer use efficiency and water use efficiency. Thus, growers' wisdom to select high-yielding varieties with better agronomic traits that match the ever-changing stresses in field conditions. It is also a fact that specified genotypes do not exhibit the same phenotypic characteristics in all environmental conditions. Thus, improved cultivar selection is an important tool for improving productivity. Western hot arid region soils are thirsty and hungry and also suffers from various atmospheric stresses (Bal and Minhas, 2017). Mustard is a crop of tropical as well as temperate zones requiring somewhat cool and dry weather for satisfactory growth and development. High temperature at flowering stage causes reduction in seed yield as it may lead to pollen sterility (Singh et al., 2014). Although mustard is a long day plant requiring $16 \mathrm{~h}$ of light period in $24 \mathrm{~h}$ cycle, it can made to flowering if it is provided with a cycle of $8 \mathrm{~h}$ of light period with $4 \mathrm{~h}$ of dark period (short night). Mustard can be made to flower in about 50 days under $16 / 8 \mathrm{~h}$ light/dark period. Growing degree days (GDD), photo-thermal index (PTI) and heat use efficiency (HUE) have frequently been used as weather-based parameters for assessing crop phenology. Therefore, all growth and development stages of crop may be estimated more accurately on the basis of GDD rather than calendar method (Warthington and Hatchinson 2005). Mustard crop require different amount of GDD, PTI and HUE for growth and development stages. The GDD is used to quantify effect of temperature and described the timing of different biological process (McMaster and Wilhelm, 1997, Qiao-yan et al., 2012). This research article on mustard (Brassica juncea L.) varieties under Azadirachta indica shade and open environmental conditions of was undertaken and results are being presented.

\section{MATERIALS AND METHODS}

A field experiment was conducted on Indian mustard (Brassica juncea L.) varieties under Azadirachta indica shade and open environmental conditions of hot arid region of Rajasthan at Instructional Farm, College of Agriculture, SK. Rajasthan Agricultural University, Bikaner, Rajasthan, 
India during rabi season of 2017-18. The experiment location situated at $28^{\circ} 01^{\prime} \mathrm{N}$ latitude and $73^{\circ} 22^{\prime} \mathrm{E}$ longitude at an altitude of 234.70 meters above mean sea level. The experiment was laid out in Factorial Randomized Complete Block Design with three replications. The factor first mustard varieties in four levels viz, varieties (RGN-73, RGN-229, RH30 and Pusa bold) and second factor two environment conditions (fully open environment and partly neem shade). The soils of experimental site were loamy sand in texture with available nutrient status $120 \mathrm{~kg} \mathrm{~N} \mathrm{ha}^{-1}, 21 \mathrm{~kg} \mathrm{P}_{2} \mathrm{O}_{5} \mathrm{ha}^{-1}$ and $296 \mathrm{Kg} \mathrm{K}_{2} \mathrm{O} \mathrm{ha}^{-1}$, saline in soil $\mathrm{pH} \mathrm{8.10.} \mathrm{The} \mathrm{temperature}$ conditions always at extreme level both sides i.e, low and high and seldom and very low winter rains. There was no winter rain received during study period. The mustard crop was sown on 17 November, 2017 using seed rate at 4 $\mathrm{kg} \mathrm{ha}^{-1}$ at row spacing $30 \mathrm{~cm}$. Besides, package of practice of raising mustard in zone 1c (Hyper Arid Partial Irrigated Zone) of Rajasthan was followed and standard procedure was adopted for recording observations. Observations were recorded on plant height, number of branch, dry matter accumulation, siliquae plant ${ }^{-1}$, test weight, seed and stover yield, biological yield and harvest index. Five random plants from each plot were uprooted and later cleaned and observations like plant height, number of branch and dry matter at periodical at 50,75, 100 and at harvest days after sowing (DAS) were recorded and averaged. Yield attributes were recorded at harvest to assess the contribution towards yield. Total number of siliquae of 5 sampled plants were counted and expressed as number of siliquae per plant. The test weight was counted from the lot, weighed and expressed as test weight. The seed and stover yields were computed from the harvest of the net plots.

The daily meteorological data was collected from Agro-meteorological Observatory, Agriculture Research Stations, Beechwal, SK. Rajasthan Agricultural University, Bikaner, Rajasthan (India), meteorological data were used (Fig.1). Agro-meteorological indices were calculated on daily basis and accumulated during different phenological stages viz. emergence, leaf development, inflorescences emergence, flowering, siliquae development, physiological maturity and at harvest of the crop using following formula: Growing degree days $(\mathrm{GDD})=\sum_{i=1}^{n}\left\{\left(\frac{T \max +T \min }{2}\right)-T \boldsymbol{b}\right\}$ $\mathrm{T}_{\mathrm{b}}=4.4^{\circ} \mathrm{C}$ (Kuar et al., 2006; Pankaj et al., 2014; Lal, et al., 2017)

Pheno-thermal index (PTI) is the ratio of degree days consumed between two phenological stages to the number of days taken between two stages (Singh et al., 2014; Lal, et al., 2017; Gupta et al., 2017).

Pheno-thermal index $(\mathrm{PTI})=\frac{\text { Accumulated growing degree days (AGDD) }}{\text { Number of days between two phenological stages }}$

Heat use efficiency (HUE) was also computed for seed yield, stove yield and biological yield.HUE $\left(\mathrm{kg} \mathrm{ha}^{-10} \mathrm{C}^{-1}\right.$ days $)$ is the dry matter produced per unit degree day consumption (Singh et al., 2014; Aggarwal et al., 2016; Sidhu et al., 2017; Lal, et al., 2017).

Heat use efficiency $\left(\mathrm{Kg} / \mathrm{ha} /{ }^{\circ} \mathrm{C}\right.$ days $)=\frac{\text { Above ground dry matter }(\mathrm{kg} / \mathrm{ha})}{\text { Accumulated growing degree days }(\mathrm{AGDD})}$

Data were statistical analyzed with STAR (Statistical Tool For Agricultural Research), software developed by Department of Plant Breeding Genetics and Biotechnology, IRRI (International Rice Research Institute), Manila, Phillipines based on the procedure of Cochran and Cox (1966).

\section{RESULTS AND DISCUSSION}

\section{Crop phenology}

The emergence was recorded as the number of days required from sowing to the date when coleoptyle had emerged on soil surface (Table 1). Days taken for completion of crop emergence and inflorescence emergence were noted non-significant effect among varieties however, Pusa bold (21.5 days) require significantly more days taken for leaf development stage than other varieties. Whereas, flowering stage in Pusa bold (55.5 days) taken less days compared to other varieties. This might be due to favourable soil and air temperature during this sowing time which hastened the seed germination and emergence (Gupta et al., 2017). Among the varieties RGN-229 taken was more days for their completion of life cycle compared to other varieties owing to genotypes characteristics of RGN-229 variety at different phenophases fruit development (91.5 days), physiological maturity (119 days) and harvesting maturity (135 days). This could be possible due to higher temperature after flower bud initiation stage which fulfilled growing degree days requirement of crop. Almost similar findings were reported by Hokmalipour et al., 2011 and Gupta et al., 2017. The shade condition was statistical significant as more days taken to achieve all the phenological stages likes that emergence (4.3 days), inflorescences emergence ( 46 days), flowering (58.3 days), fruit development (88.4 days), physiological maturity (116.8 days) and harvesting maturity (128 days) compared to open condition. 


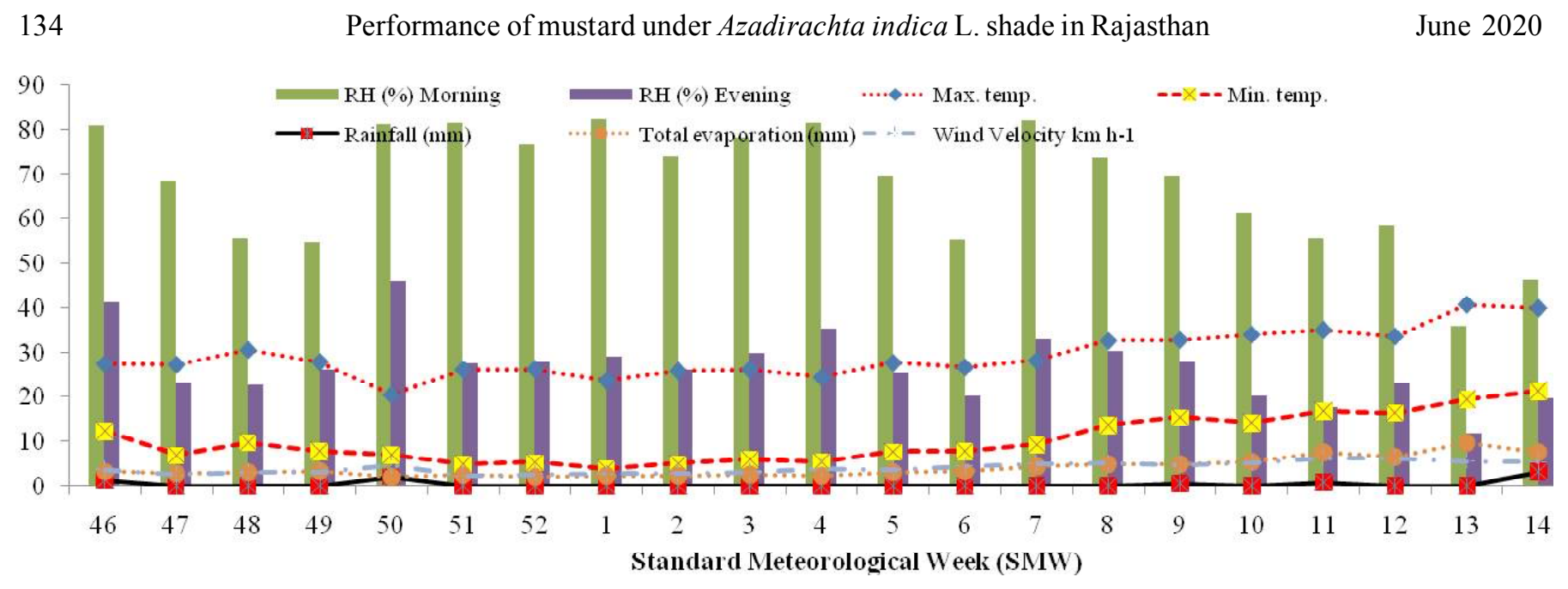

Fig.1: Mean weekly meteorological conditions during the crop Rabi season (2017-18)

Table 1: Effect of varieties and environmental condition on phenological stage (DAS) of mustard.

Treatment Emergence Development Inflorescences Flowering Development Physiological Harvesting of leaf emergence of fruit maturity maturity

\section{A. Varieties}

\begin{tabular}{lrrrrrrr} 
i. RGN-73 & 3.5 & 19.3 & 45.7 & 58.0 & 89.5 & 116.2 & 129.5 \\
ii. RGN-229 & 3.5 & 19.3 & 45.7 & 58.0 & 91.5 & 119.0 & 135.0 \\
iii. RH-30 & 4.2 & 20.2 & 45.5 & 58.0 & 85.5 & 116.0 & 126.0 \\
iv. Pusa bold & 4.0 & 21.5 & 44.8 & 55.5 & 85.3 & 111.5 & 119.0 \\
CD (p=0.05) & NS & 1.7 & NS & 1.5 & 0.9 & 1.1 & 1.2 \\
B. Environment conditions & & & & & & & \\
i. Open & 3.3 & 19.7 & 44.8 & 56.5 & 87.5 & 114.6 & 126.8 \\
ii. Shade (Neem) & 4.3 & 20.4 & 46.0 & 58.3 & 88.4 & 116.8 & 128.0 \\
$\mathrm{CD}(\mathrm{p}=0.05)$ & 0.8 & $\mathrm{NS}$ & 0.9 & 1.1 & 0.7 & 0.8 & 0.9 \\
\hline
\end{tabular}

Table 2: Response of mustard varieties and environmental conditions on plant height $(\mathrm{cm})$.

\begin{tabular}{|c|c|c|c|c|}
\hline Treatment & 50DAS & 75DAS & 100DAS & At harvest \\
\hline \multicolumn{5}{|l|}{ A. Varieties } \\
\hline i. RGN-73 & 33.4 & 130.7 & 137.7 & 140.8 \\
\hline ii. RGN-229 & 33.7 & 126.0 & 141.0 & 144.3 \\
\hline iii. $\mathrm{RH}-30$ & 40.3 & 123.7 & 131.7 & 135.0 \\
\hline iv. Pusa bold & 37.8 & 134.8 & 147.7 & 151.0 \\
\hline $\mathrm{D}(\mathrm{p}=0.05)$ & 5.1 & NS & 6.8 & 5.6 \\
\hline \multicolumn{5}{|c|}{ B. Environment conditions } \\
\hline i. Open & 38.7 & 138.6 & 153.9 & 157.3 \\
\hline ii. Shade (Neem) & 34.2 & 119.1 & 125.0 & 128.3 \\
\hline $\mathrm{CD}(\mathrm{p}=0.05)$ & 3.6 & 12.4 & 4.8 & 3.9 \\
\hline
\end{tabular}

\section{Plant height}

Among the Mustard varieties, RH 30 was attained tested the maximum plant height $(40.3 \mathrm{~cm})($ Table 2$)$ was noted at 50 DAS over RGN-73 and RGN-229 but was at par with Pusa bold $(37.8 \mathrm{~cm})$. While at 100DAS and at harvest significantly higher plant height was recoded in variety 
Table 3: Effect of mustard varieties and environmental conditions on number of branches per plant.

\begin{tabular}{|c|c|c|c|c|}
\hline Treatment & 50DAS & 75DAS & 100DAS & At harvest \\
\hline \multicolumn{5}{|l|}{ A. Varieties } \\
\hline i. $\mathrm{RGN}-73$ & 2.5 & 4.8 & 6.8 & 7.0 \\
\hline ii. RGN-229 & 2.4 & 4.6 & 6.5 & 6.8 \\
\hline iii. $\mathrm{RH}-30$ & 1.7 & 3.3 & 4.6 & 4.9 \\
\hline iv. Pusa bold & 1.9 & 4.3 & 5.2 & 5.9 \\
\hline $\mathrm{CD}(\mathrm{p}=0.05)$ & 0.1 & NS & 1.5 & 1.1 \\
\hline \multicolumn{5}{|c|}{ B. Environment conditions } \\
\hline i. Open & 2.6 & 5.5 & 7.7 & 8.1 \\
\hline ii. Shade (Neem) & 1.7 & 3.0 & 3.9 & 4.2 \\
\hline $\mathrm{CD}(\mathrm{p}=0.05)$ & 0.1 & 0.9 & 1.0 & 0.8 \\
\hline
\end{tabular}

Table 4: Response of mustard varieties and environmental conditions on dry matter accumulation per plant (g).

\begin{tabular}{|c|c|c|c|c|}
\hline Treatment & 50DAS & 75DAS & 100DAS & At harvest \\
\hline \multicolumn{5}{|l|}{ A. Varieties } \\
\hline i. $\mathrm{RGN}-73$ & 3.0 & 10.3 & 20.5 & 27.9 \\
\hline ii. RGN-229 & 2.2 & 8.6 & 17.0 & 25.1 \\
\hline iii. $\mathrm{RH}-30$ & 1.8 & 6.4 & 12.7 & 18.4 \\
\hline iv. Pusa bold & 2.1 & 6.8 & 13.5 & 19.7 \\
\hline $\mathrm{CD}(\mathrm{p}=0.05)$ & 0.2 & 1.3 & 2.5 & 3.4 \\
\hline \multicolumn{5}{|c|}{ B. Environment conditions } \\
\hline i. Open & 2.9 & 9.2 & 18.2 & 25.8 \\
\hline ii. Shade (Neem) & 1.6 & 6.8 & 13.6 & 19.8 \\
\hline $\mathrm{CD}(\mathrm{p}=0.05)$ & 0.2 & 0.9 & 1.7 & 2.4 \\
\hline
\end{tabular}

Pusa bold i.e. 147.7 and $151 \mathrm{~cm}$, respectively. The plant height under shade environmental condition decreased significantly compared to open condition at all the periodical stage. The maximum plant height was noted in open environmental condition at 50 DAS to at harvest DAS were $38.7,138.6,153.9$ and $157.3 \mathrm{~cm}$, respectively.

\section{Number of branches and dry matter accumulation}

Among the mustard varieties in RGN-73 showed superior at all the periodical stages significantly increased number of branches plant ${ }^{-1}$ (Table-3) and dry matter accumulation plant ${ }^{-1}$ (Table-4). It was due to high yielding variety suitable for irrigated condition. Similar result was found by (Bagwar, 2016). The maximum numbers of branches plant $^{-1}$ in RGN-229 variety noted at different periodical stages like that 50,75, 100 DAS and at harvest were 2.5, 4.8, 6.8 and 7.0, respectively. The less number of branch plant $^{-1}$ under RH-30 was 1.7, 3.3, 4.6 and 4.9 at 50, 75, 100
DAS and at harvest, respectively. Whereas, significantly higher number of branches plant ${ }^{-1}$ and dry matter were noted under open condition compared to shade condition. The highest number of branch plant ${ }^{-1}(8.1)$ and dry matter plant ${ }^{1}(25.8 \mathrm{~g})$ were recorded in open environment as compared to respective value 4.2 number plant ${ }^{-1}$ in Neem shade growing environment. Hence, more radiation available resulting higher photosynthesis in open condition and reduced height reached to plants under neem shade condition thereby decreased rate of photosynthesis of dry matter accumulation.

\section{Yield attributes, yield and harvest index}

The number of siliquae plant ${ }^{-1}$ (Table 5) in RGN-73 (170.1) was statistically significant compared to other treatments. Similar result was recorded in seed yield (1231 $\left.\mathrm{kg} \mathrm{ha}^{-1}\right)$, stover yield (4597 $\left.\mathrm{kg} \mathrm{ha}^{-1}\right)$, biological yield (5828 $\mathrm{kg} \mathrm{ha}^{-1}$ ) presented in Fig. 2 and 3). Whereas, test weight in Pusa bold was significantly higher recorded than other 
Table 5: Influence of mustard varieties and environmental conditions on yield attributes, harvest index and heat use efficiency (HUE) $\left(\mathrm{kg} \mathrm{ha}^{-1} \mathrm{C}^{-1}\right.$ days) of yield.

\begin{tabular}{|c|c|c|c|c|c|c|}
\hline \multirow[t]{2}{*}{ Treatment } & \multirow{2}{*}{$\begin{array}{l}\text { No. of } \\
\text { Siliquae/plant }\end{array}$} & \multirow{2}{*}{$\begin{array}{l}\text { Test } \\
\text { weight }(\mathrm{g})\end{array}$} & \multirow{2}{*}{$\begin{array}{l}\text { Harvest } \\
\text { index }(\%)\end{array}$} & \multicolumn{3}{|c|}{ Heat use efficiency $\left(\mathrm{kg} \mathrm{ha}^{-1}{ }^{\circ} \mathrm{C}^{-1}\right.$ days $)$} \\
\hline & & & & $\overline{\text { Seed yield }}$ & Stover Yield & Biological yield \\
\hline \multicolumn{7}{|l|}{ A. Varieties } \\
\hline i. $\mathrm{RGN}-73$ & 170.1 & 3.9 & 20.8 & 4.2 & 15.5 & 19.7 \\
\hline ii. RGN-229 & 158.0 & 3.7 & 20.5 & 3.7 & 14.1 & 17.8 \\
\hline iii. $\mathrm{RH}-30$ & 125.0 & 4.9 & 18.9 & 3.2 & 13.6 & 16.8 \\
\hline iv. Pusa bold & 118.6 & 5.1 & 18.3 & 3.3 & 14.5 & 17.8 \\
\hline $\mathrm{CD}(\mathrm{p}=0.05)$ & 3.3 & 0.3 & 1.6 & 0.5 & 1.0 & 1.2 \\
\hline \multicolumn{7}{|c|}{ B. Environment conditions } \\
\hline i. Open & 172.6 & 4.6 & 22.9 & 4.4 & 14.8 & 19.3 \\
\hline ii. Shade (Neem) & 113.3 & 4.1 & 16.4 & 2.8 & 14.0 & 16.8 \\
\hline $\mathrm{CD}(\mathrm{p}=0.05)$ & 2.3 & 0.2 & 1.2 & 0.3 & 0.7 & 0.8 \\
\hline
\end{tabular}

Table 6: Effect of varieties and environmental condition on growing degree days (GDD) $\left({ }^{\circ} \mathrm{C}\right.$ days) of different phonological stage of mustard

\begin{tabular}{|c|c|c|c|c|c|c|c|}
\hline Treatment & Emergence & $\begin{array}{r}\text { Development } \\
\text { of leaf }\end{array}$ & $\begin{array}{r}\text { Inflorescences } \\
\text { emergence }\end{array}$ & Flowering & $\begin{array}{r}\text { Development } \\
\text { of Fruit }\end{array}$ & $\begin{array}{r}\text { Physiological } \\
\text { maturity }\end{array}$ & $\begin{array}{r}\text { Harvesting } \\
\text { maturity }\end{array}$ \\
\hline \multicolumn{8}{|l|}{ A. Varieties } \\
\hline i. $\mathrm{RGN}-73$ & 51.8 & 286.1 & 675.9 & 858.4 & 1324.6 & 1719.26 & 1916.6 \\
\hline ii. RGN-229 & 51.8 & 286.1 & 675.9 & 858.4 & 1324.2 & 1761.2 & 1998.0 \\
\hline iii. $\mathrm{RH}-30$ & 61.7 & 298.5 & 675.4 & 858.4 & 1265.4 & 1716.8 & 1864.8 \\
\hline iv. Pusa bold & 59.2 & 318.2 & 663.5 & 821.4 & 1262.9 & 1650.2 & 1764.2 \\
\hline C.D. $(p=0.05)$ & NS & 25.2 & NS & 22.0 & 14.1 & 16.8 & 18.4 \\
\hline \multicolumn{8}{|c|}{ B. Environment conditions } \\
\hline i. Open & 49.3 & 292.3 & 663.5 & 836.2 & 1295.0 & 1695.8 & 1875.9 \\
\hline ii. Shade (Neem) & 62.9 & 302.2 & 680.8 & 862.1 & 1308.5 & 1727.9 & 1894.4 \\
\hline C.D. $(p=0.05)$ & 11.4 & NS & 12.8 & 15.5 & 10.0 & 11.9 & 13.0 \\
\hline
\end{tabular}

varieties. This might be due to genotype characteristics and high yielding potential of the variety suitable for irrigated condition. Similar result was found by (Bagwar, 2016). The maximum harvest index under RGN-73 (20.8\%) was higher but statistical at par with RGN-229 (20.5\%), while both varieties were significantly superior than RH-30 (18.9\%) and Pusa bold (18.3\%). Result showed that irrespective of varieties, more number of siliquae plant ${ }^{-1}$ (172.6) and test weight $(4.6 \mathrm{~g})$ were noted under open condition compared to shade condition. Seed yield (1307 $\left.\mathrm{kg} \mathrm{ha}^{-1}\right)$, stover yield (4391 $\left.\mathrm{kg} \mathrm{ha}^{-1}\right)$, biological yield $\left(5699 \mathrm{~kg} \mathrm{ha}^{-1}\right)$ and harvest index $(22.9 \%)$, noted were higher in open condition as compared to shade environmental condition. This might possibly due to more availability of solar energy to plants for photosynthesis thereby accumulation of carbon. Moreover, higher values of yield and harvest index were observed in open environment in comparison to neem shade condition in all varieties. This show proper synthesis and distribution of accumulated dry matter or carbon partitioning towards developing sink i.e. higher harvest index noted in open condition Heat stress during the post anthesis seed ${ }^{-1}$ filling negatively influences the movement of photosynthates to the developing sinks and inhibits the synthetic processes, thus causes lower seed weight, seed yield and may alter seed quality (Kumari et al., 2004).

\section{Growing degree days (GDD)}

The accumulated thermal units required for mustard 

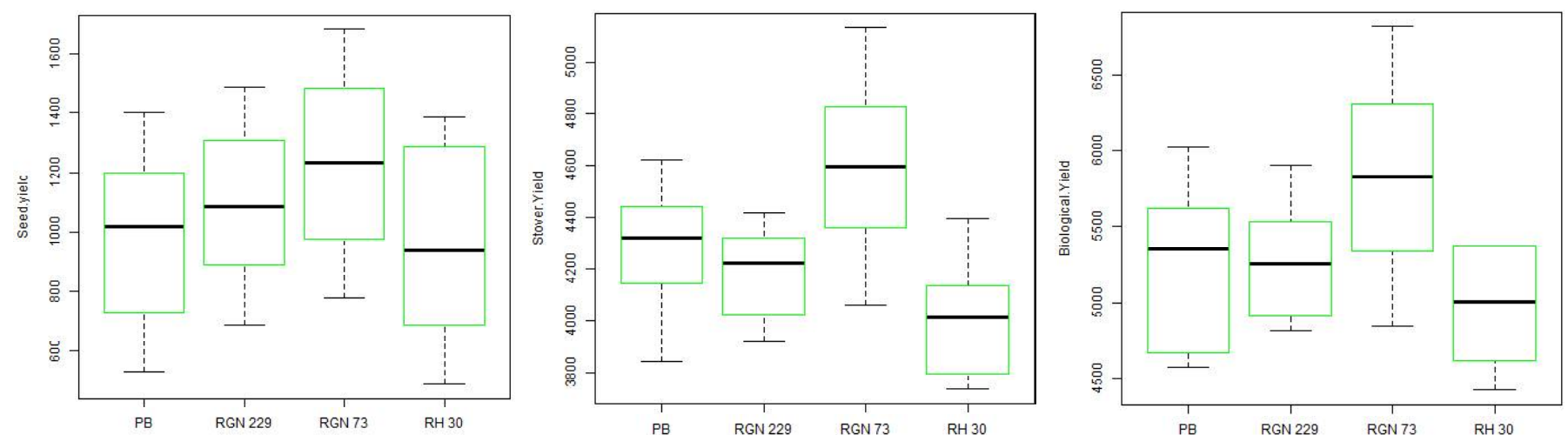

Fig. 2: Box plots show that variability of mustard varieties on seed yield, stover yield and biological yield
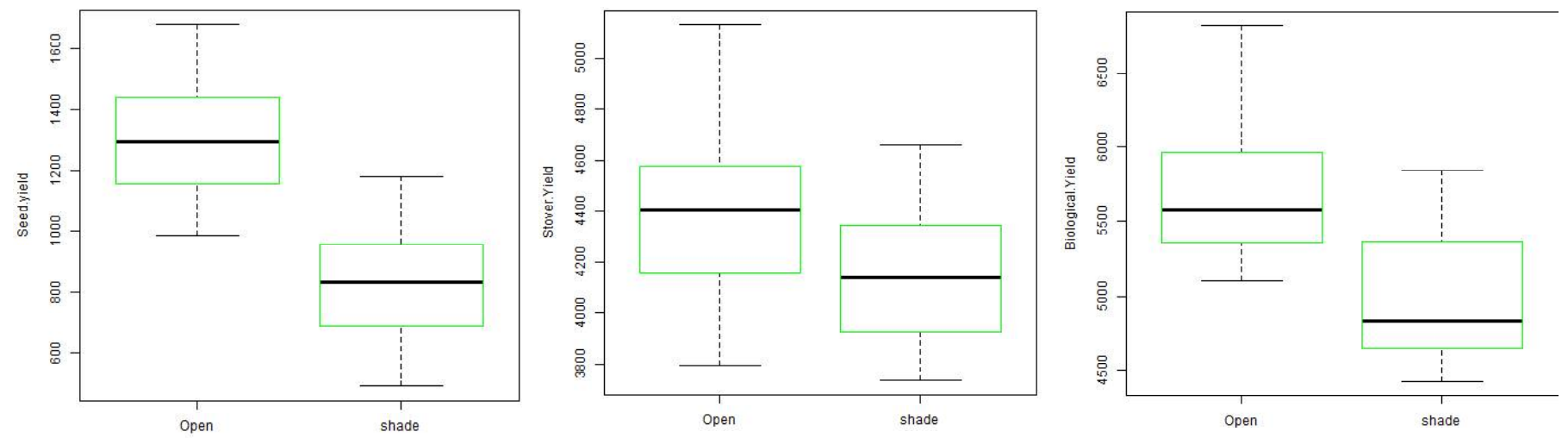

Fig. 3: Box plots show that variability of environmental conditions on seed yield, stover yield and biological yield of mustard

Table 7: Effect of varieties and environmental condition on pheno-thermal index (PTI) of different phonological stage of mustard

\begin{tabular}{|c|c|c|c|c|c|c|c|}
\hline Treatment & Emergence & $\begin{array}{r}\text { Development } \\
\text { of leaf }\end{array}$ & $\begin{array}{r}\text { Inflorescences } \\
\text { emergence }\end{array}$ & Flowering & $\begin{array}{r}\text { Development } \\
\text { of Fruit }\end{array}$ & $\begin{array}{r}\text { Physiological } \\
\text { maturity }\end{array}$ & $\begin{array}{r}\text { Harvesting } \\
\text { maturity }\end{array}$ \\
\hline \multicolumn{8}{|l|}{ A. Varieties } \\
\hline i. $\mathrm{RGN}-73$ & 92.1 & 18.8 & 11.3 & 24.3 & 9.4 & 11.1 & 22.3 \\
\hline ii. $\mathrm{RGN}-229$ & 92.1 & 19.0 & 11.3 & 24.2 & 8.9 & 10.8 & 18.6 \\
\hline iii. $\mathrm{RH}-30$ & 73.2 & 18.7 & 11.7 & 24.0 & 10.8 & 9.7 & 30.5 \\
\hline iv. Pusa bold & 77.3 & 16.9 & 12.7 & 28.4 & 9.9 & 11.4 & 40.9 \\
\hline C.D. $(p=0.05)$ & NS & NS & 0.6 & NS & 0.6 & 0.7 & 7.6 \\
\hline \multicolumn{8}{|c|}{ B. Environment conditions } \\
\hline i. Open & 95.4 & 18.2 & 11.9 & 26.0 & 9.6 & 11.0 & 26.2 \\
\hline ii. Shade (Neem) & 72.0 & 18.5 & 11.6 & 24.7 & 9.9 & 10.5 & 30.0 \\
\hline C.D. $(p=0.05)$ & 21.6 & NS & NS & NS & NS & 0.5 & NS \\
\hline
\end{tabular}

crop to attain different phenophases varied with varieties and environment condition. Among the varieties, crop emergence and inflorescence emergence non-significant variation was observed in respect of consuming degree days (Table 6). Among the varieties in Pusa bold at leaf development stage $\left(318.2{ }^{\circ} \mathrm{C}\right.$ days $)$ was significantly more consumed degree days compared to RGN-73 $\left(286.1{ }^{\circ} \mathrm{C}\right.$ - days) and RGN-229 (286. $1^{\circ} \mathrm{C}$-days) but at par with RH-30 (298.5 ${ }^{\circ} \mathrm{C}$-days). GDD statistically on par among RGN-229 and RGN-73 were significantly more than varieties, $\mathrm{RH}-30$ and Pusa bold both at flowering and fruit development stage. Physiological maturity $\left(1761.2{ }^{\circ} \mathrm{C}\right.$-days $)$ and harvesting maturity $\left(1998^{\circ} \mathrm{C}\right.$-days $)$ were consumed more degree days in RGN-229 compared to other varieties. This 
might be due to genotypes characteristics and long duration of the variety. The varietal differences in mustard for phasic duration and thermal units were also reported by Goswami et al., (2003), Khushu et al., (2008) and Tharranum et al., (2016). The shade condition was statistical significant require more degree days at all the phonological stage likes that emergence $\left(62.9^{\circ} \mathrm{C}\right.$-days $)$, inflorescences emergence $(680.8$ ${ }^{\circ} \mathrm{C}$-days), flowering $\left(862.1{ }^{\circ} \mathrm{C}\right.$-days $)$, fruit development (1308.6 ${ }^{\circ} \mathrm{C}$-days), physiological maturity $\left(1727.9^{\circ} \mathrm{C}\right.$-days $)$ and harvesting maturity $\left(1894.4{ }^{\circ} \mathrm{C}\right.$-days) compared to open condition. It might be due to initial lower while, increase with duration of crop which increased the thermal efficiency. Similar results were also reported by (Gupta et al., 2017).

\section{Heat use efficiency (HUE)}

Heat use efficiency was found to be higher in variety RGN-73 at seed $\left(4.2 \mathrm{~kg} \mathrm{ha}^{-1}{ }^{\circ} \mathrm{C}\right.$-days $\left.{ }^{-1}\right)$, stover $\left(15.5 \mathrm{~kg} \mathrm{ha}^{-}\right.$ ${ }^{1}{ }^{\circ} \mathrm{C}$-days $\left.{ }^{-1}\right)$ and biological yield $\left(19.7 \mathrm{~kg} \mathrm{ha}^{-1}{ }^{\circ} \mathrm{C}\right.$-days $\left.{ }^{-1}\right)$ followed by RGN-229, Pusa bold and RH-30 (Table 5). Heat use efficiency in open environmental condition treatment at seed $\left(4.4 \mathrm{~kg} \mathrm{ha}^{-1}{ }^{\circ} \mathrm{C}\right.$-days $\left.{ }^{-1}\right)$, stover $\left(\mathrm{kg} \mathrm{ha}^{-1}{ }^{\circ} \mathrm{C}\right.$-days $\left.{ }^{-1}\right)$ and biological yield $\left(19.3 \mathrm{~kg} \mathrm{ha}^{-1}{ }^{\circ} \mathrm{C}\right.$-days $\left.{ }^{-1}\right)$ were significantly greater than neem shade environmental condition because heat use efficiency depended on biomass production and production increased with increase of heat use efficiency (Ahatsham et al., 2018), which is a measure of amount of dry matter production per unit of thermal unit, worked out as per procedures reported by Sahu et al., (2007). HUE increased from vegetative growth to reproductive growth stages; however, it decreased slightly at physiological maturity of the crop (Gupta et al., 2017; Lal et al., 2017). Irrespective of growing environments, the increase in HUE was maximum during reproductive phase. Varietal difference for HUE was also found at all growth stages of crop growth. Pusa Jai Kisan variety of mustard recorded higher value of HUE at all growth stages followed by Pusa Bold and Varuna (Tyagi, 2017).

\section{Pheno thermal index (PTI)}

Inflorescence emergence was significantly superior in Pusa bold (12.7) compared to other varieties (Table 7). The fruit development was better in variety RH-30 (10.8) than other variety. The physiological maturity and harvesting maturity were higher under Pusa bold variety. Similar results on PTI were supported by Prasanta, 2005. Under open environmental condition, statistical significance was observed for emergence (95.4) and physiological maturity but non-significant for leaf development, inflorescences emergence, flowering, fruit development, and harvesting maturity. PTI gradually decreased from emergence to later phenological stages of crop, being highest at emergence and lowest at most seeds brown stage; however, the values of PTI at emergence stage indicating a decrease in daily heat consumption towards maturity (Gupta et al., 2017). This might be due to gradual decrease in day and night temperature, which resulted in decrease in PTI of that phenophase as the sowing was delayed (Neog et al., 2008).

\section{CONCLUSION}

It was concluded that, Varity RGN-73 recorded highest seed, stove and biological yield followed by RGN229, RH-30 and Pusa bold. The days taken from planting to harvesting took maximum calendar days and more growing degree days for variety RGN-229 and shade environmental condition. The heat use efficiency and photo-thermal index were better in RGN-73 variety and partial shade environment condition.

\section{ACKNOWLEDGEMENT}

The authors are heartily thankful to the Head, Department of Agronomy, College of Agriculture, SKRAU, (Bikaner) for providing student's practical field trial facilities. Author is also thankful to the anonymous reviewer/referee for the valuable suggestions and comments to improve the paper.

\section{REFERENCES}

Aggarwal, N., Singh, A. and Singh, S.P. (2016). Heat utilization and radiation interception in transplanted rice (Oryza sativa $\mathrm{L}$.) in relation to seedling age. J. Agrometerol., 18 (1): 93-96.

Ahatsham, M., Singh, S. and Dagar, C.K. (2018). Heat Use Efficiency of Indian mustard (Brassica juncea L.) at Different Phenophases in Western Haryana, India.Int. J. Curr. Microbiol. App. Sci., 7(6): 1977-1981.

Alam, M.J.,Ahmed, K.S., Mollah, M.R.A., Tareq, M.Z.andAlam, J. (2015). Effect of Planting Dates on the Yield of Mustard Seed. Int. J. Applied Sci. Biotech., 3(4): 651625.

Bal, S.K. and Minhas, P.S. (2017). Atmospheric Stressors: Challenges and Coping Strategies. In: "Abiotic Stress Management for ResilientAgriculture".(Eds. P.S. Minhas et al.). pp. 9-50, Springer Nature Singapore Pte. Ltd.

Bagwar, S. (2016). Agro-physiological screening of Indian mustard varieties in Tikamgarh district of Bundelkhand region. M.Sc. thesis submitted to Jawaharlal Nehru Krishi Vishwa Vidyalaya, Jabalpur. 
Buttar, G.S. and Aulakh, C.S. (1999). Effect of sowing date, nitrogen and row spacing on growth, yield attributes and yield of Indian mustard (Brassica juncea). Indian J. Agron., 44(4): 813-815.

Cochran, W.G. and Cox, G.M. (1966). ExperimentDesigns. Asia publishing House, New Delhi, India.

FAO, (2007). FAO (Food and agricultural Organization) FAO Production year Book. Rome, Italy, Vol. 61. p.64.

Goswami, B., Mahi, G.S., Hundal, S.S. and Saikia, U.S. (2003). Growing degree days for rice and wheat in Ludhiana region. J. Agrometeorol., 5(1): 117-119.

Gupta, M., Sharma, C., Sharma, R., Gupta, V. and Khushu, M.K. (2017). Effect of sowing time on productivity and thermal utilization of mustard (Brassica juncea) under sub-tropical irrigated conditions of Jammu. $J$. Agrometeorol., 19(2): 137-141.

Hokmalipour, S., Tobe, A., Jafarabad, B. and Darbandi, M.H. (2011). Effect of sowing date on drymatter accumulation trend, yield and some agronomic characteristics in canola (Brassica napus L.) cultivars. Wor. App. Scs. J., 19 (7): 996-1002.

Kaur, P., Khehra, M.K. and Hundal, S.S. (2006). Development of thermo-based phenophasic model for predicting phonological stages of Indian mustard (Brassicajuncea) in central plains of Punjab. Ind. J. Agri. Sci., 76(6): 37779.

Khushu, M.K., Naseer-U-Rahman, Singh, M., Prakash,A., Tiku, A.K. andBali,A.S.(2008). Thermal time indices for some mustard genotypes in the Jammu region. $J$. Agrometeorol., 10 (2): 224-227.

Kumari, Radha C., Koteswararao, D.S. and Obulamma, U. (2004). Impact of sowing dates and land treatments on Indian mustard (Brassica juncea) in nontraditional areas of Andhra Pradesh. Madras Agric. J., 91 (7-12):374-377.

Kumawat,A., Pareek, B.L, Yadav, R.S. and Rathore, P.S. (2014). Effect of integrated nutrient management on growth, yield, quality and nutrient uptake of Indian mustard (Brassica juncea) in arid zone of Rajasthan. Ind. J. Agron., 59(1): 119123.

Lal, M., Saini, K.S. and Prabhjyot-Kaur(2017). Phenological Development and Agrometeorological Indices in Dual Purpose Barley (Hordeum vulgare L.) as Influenced by Planting Techniques and Cutting Practices in IndoGangetic Plains of India. Ind. J. Ecol., 44(3): 570-574.
McMaster, G.S. and Wilhelm, W.W. (1997). Growing degree days: One equation, two interpretations. Agric. Forest. Meteorol., 87, 291-300.

Neog, P., Bhuyan, J. and Baruah, N. (2008). Thermal indices in relation to crop phenology and seed yield of soybean (Glycine max L.). J. Agrometeorol., (Special Issue-part 2), 388-392.

Pankaj, S.C., Sharma, P.K. and Kingra, P.K. (2014). Thermal energy requirement and heat use efficiency of barley varieties under different dates of sowing. Indian $J$. Ecol., 41(2): 247-51.

Prasanta, N.C. (2005). Thermal indices in Brassica grown under a semi-arid environment. Ann. Agric. Res., 26(2): 291296.

Qiao-yan, L.I., Jun, Y.I.N., Wan-dai, Liu., Mei, Zhou., Lei, L.I. and Jishan, N. (2012). Determination of optimum growing degree days (GDD) range before winter for wheat cultivars with different growth characteristics in North China Plain. J. Integr. Agric., 11: 405-415.

Sahu, D.D., Chopada, M.C. and Patoliya, B.M. (2007). Determination of sowing time for chickpea varieties in south Saurashtra, India. J. Agrometeorol., 9: 68-73

Sidhu, S.K., Kaur, J. and Singh, I. (2017). Agroclimatic indices and phenology of pigeonpea [Cajanus cajan (L.) Millsp.] in relation to its yield. J. Agrometeorol., 19(2): 129-133.

Singh, M.P., Lallu. and Singh, N.B. (2014). Thermal requirement of indian mustard (Brassica juncea) at different phonological stages under late sown condition. Indian J. Plant Physiol., 19(3): 238-243.

Tharranum, A. Mehnaj, Singh, R., Ram Niwas, Kumar, N. and Shalu, R. (2016). Thermal time requirements of ten genotypes of Brassica species at Hisar. J. Agrometeorol., 18 (1): 131-133.

Tyagi, P.K. (2017). Thermal requirements and heatuse efficiency of Indian mustard varieties under different environment. J. Agrometeorol., 19(2):164-166.

Warthinhton, C.M., and Hatchinson, C.M. (2005). Accumulated degree days as a model to determine key development stages and evacuate yield and quality of potato in Northeast Florida. Proc. State Hort. Soc., 118: 98-101. 